\title{
Introduction
}

\author{
Keith Swift with Elisa Lanza Catti
}

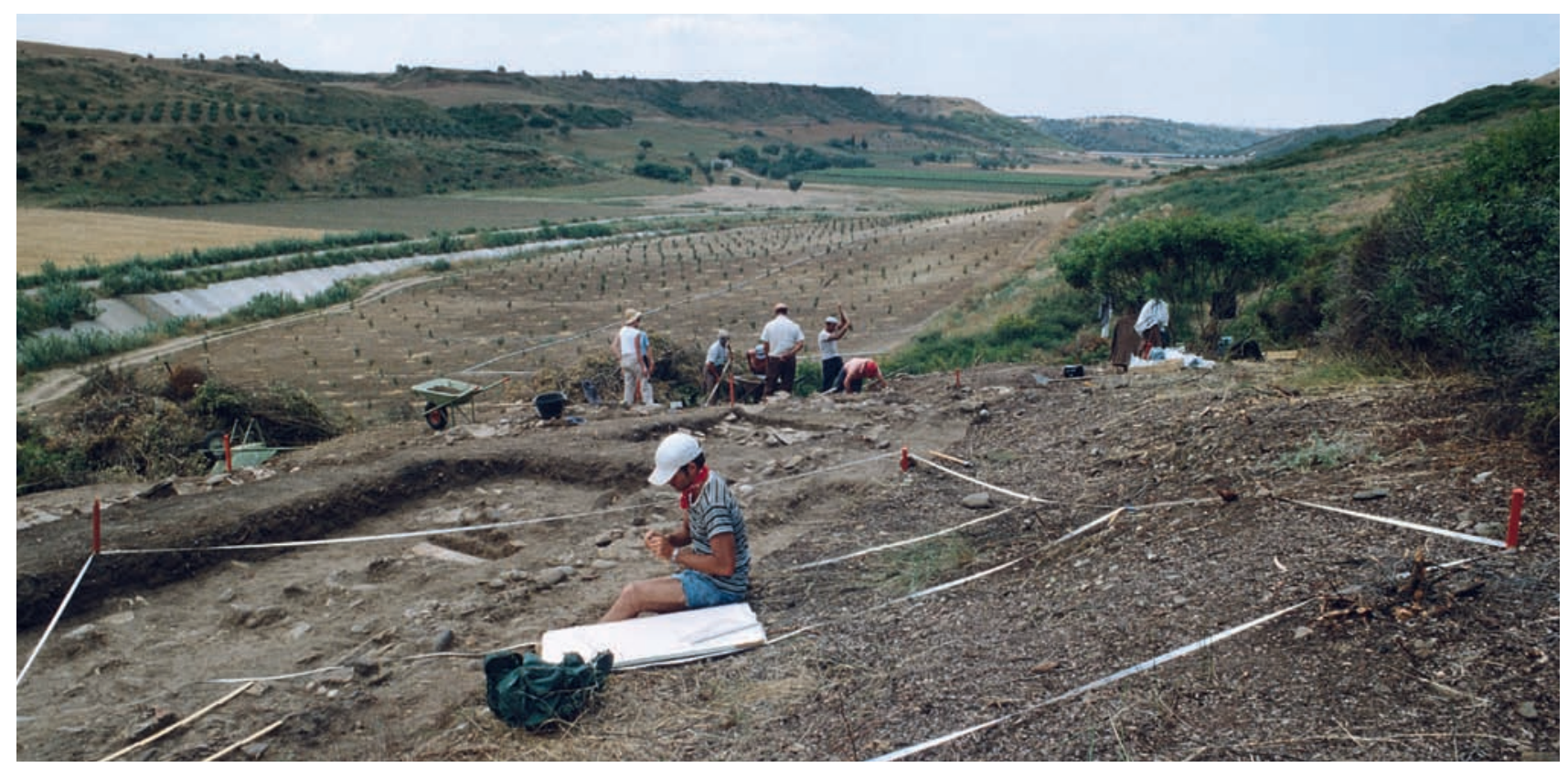

Figure i Excavation at Fattoria Fabrizio, 1980. (CLL/CW/ICA)

\section{Discovery and Excavation}

During an initial field survey of the Metapontine chora in 1980, a scatter of Archaic material was identified on a mid-slope terrace on the flanks of the Venella valley. The area is known as "Ponte Fabrizio," after the modern bridge across what is now, due to modern irrigation, a very small stream. Pottery and tile fragments extruding from a scarp were visible beneath a dense cover of macchia vegetation, and the presence of Archaic material-particularly Ionic-type cups belonging to the 6th century $\mathrm{BC}$-was promising enough to warrant an excavation, which began promptly and continued for three weeks in the summer of $1980 .{ }^{1}$

Covered by a thin topsoil and capped by a thick tile fall, the site was divided into 5-m grid squares and, once the upper layers of the tile fall had been removed, much of the floor plan of a six-room structure was apparent from stone foundation walls. It quickly became

\footnotetext{
${ }^{1}$ The excavations at Fattoria Fabrizio were carried out under the direction of Prof. Joseph C. Carter and formed part of the wider archaeological excavation and survey in the chora of Metaponto. Claire Lyons was site supervisor (see above, p. xv).
}

evident that, despite the high frequency of Archaicperiod pottery on the surface of the site and in the face of the scarp, the tile fall and underlying structure sealed beneath it belonged to a 4 th-century BC farmhouse. ${ }^{2}$

Excavations proceeded room by room and extended into the extra-mural area to the northwest, at the southeastern side of the structure. Further away, soundings were made to the southeast and northeast to determine the limits of the structure and the nature of the archaeological stratigraphy beyond the confines of the building.

\section{Geography and Environment}

The Venella River, a tributary of the Basento River with a confluence about $8.5 \mathrm{~km}$ upstream from the modern coastline, cuts through the marine terraces of the Central Plateau of the chora between the Basen-

\footnotetext{
${ }^{2}$ Carter 2006, 137. Archaic material continued to be relatively well represented in the excavated assemblages. Residual Archaic material was present to some extent in the majority of contexts (see Ch. 1). The Archaic material extruding from the scarp would, following excavation, later be seen to derive from thin Archaic contexts underlying the farmhouse structure, and from residual material in the makeup for the farmhouse.
} 


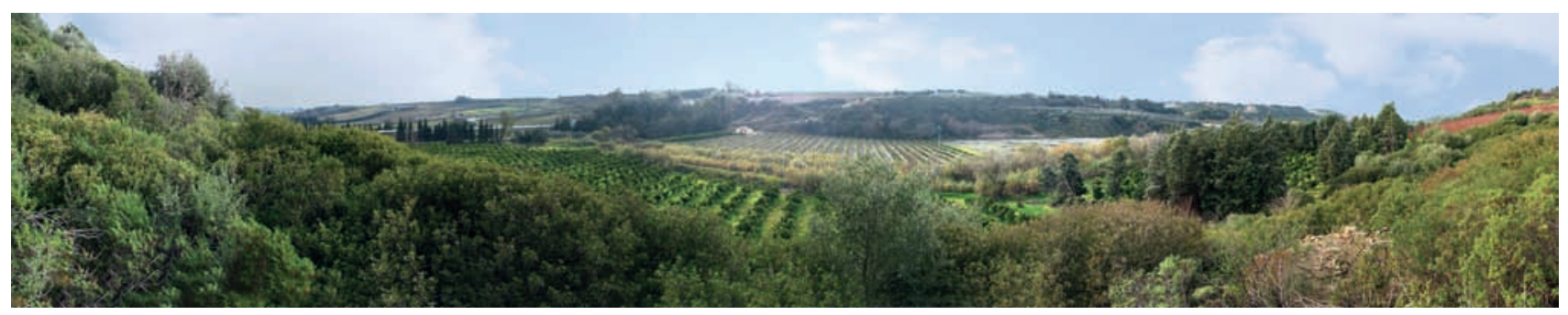

Figure ii Panoramic view of the environs of Fattoria Fabrizio looking from the site out over the Venella valley. (ML/ICA)

to and Bradano Rivers in a northwesterly direction along its $13-\mathrm{km}$ course.

The Venella valley bisects the marine terraces and their plateaus, the large Central Plateau in the areas of Lago del Lupo immediately to the north, and Avinella on the opposite side of the Venella valley. ${ }^{3}$ Lago del Lupo forms part of the expansive Central Plateau that comprises the arable heart of the chora between the Basento and Bradano Rivers. The Central Plateau was demarcated and drained by division lines following the orientation of the marine terraces and running broadly parallel to this part of the Venella, as was the Avinella on the opposite side. ${ }^{4}$ Indeed, the agricultural landscape, settlement patterns, and division lines are particularly clear on the marine terraces in the areas of Avinella and Lago del Lupo. ${ }^{5}$

A prominent modern topographic feature, the bridge Ponte Fabrizio from which the site takes its name, ${ }^{6}$ crosses the Venella valley just below the site. A modern irrigation pipe runs across the valley near the bridge, and the course of the stream is barely visible (Fig. iii).

Fattoria Fabrizio is situated on a mid-slope terrace formed from marine conglomerates, more or less equidistant from the floor and lip of the valley. Topographic constraints of the mid-slope terrace mean that the orientation of the farmhouse is at odds with the usual one of farmhouses in the chora. These are commonly aligned with the northwest-southeast orientation of the marine terraces and the division lines (for example, Fattoria Stefan), ${ }^{7}$ with a southeast-facing frontage, but Fattoria Fabrizio is oriented parallel to the valley flank and terrace, perpendicular to the division

\footnotetext{
${ }^{3}$ The localities in the Metapontine chora such as Venella, Lago del Lupo, and Avinella are discussed and described by Carter in Survey, 627-28, and Prieto in Survey, Vol. IV, 48-53. For the geological and geomorphological background of the Metapontine chora, see Folk in Survey, ch. 1, and Abbott in Survey, ch. 2.

${ }^{4}$ Carter in Survey, 1027-51, fig. 25.19, and this volume, Figure v.

${ }^{5}$ Carter in Survey, 814-16.

${ }^{6}$ Lattanzi 1981, 339; D. Ridgway 1982, 75; Osanna 1992, 80.

${ }^{7}$ Carter 2006, 143, fig. 4.13 .
}

lines and the marine terraces of the Central Plateau above and beyond the site. ${ }^{8}$

Formed from a natural outcrop of marine conglomerate, the site was well suited to habitation. Along with local sandstone, the conglomerate rock underlying Fattoria Fabrizio and forming the midslope terrace outcrops along the slope was exploited for building material for the wall foundations. The Plio-Pleistocene marine clays capped by the conglomerates and gravels provided raw materials for the mudbrick superstructure of the farmhouse. ${ }^{9}$ The spring line occurring where the conglomerate meets the Pliocene marine clays toward the valley floor would have provided a ready source of water. ${ }^{10}$

The marine terraces that form much of the chora and extend ca. 16-20 km inland were particularly well suited to arable agriculture. ${ }^{11}$ The range of crops produced in the chora is the subject of a series of palaeobotanical studies in different areas of the chora. ${ }^{12}$ Pollen analyses from Fattoria Fabrizio extend this work and provide a more localized perspective on agricultural life in the chora (see Ch. 7).

Cereals were no doubt a major crop on the marine terraces, but Fattoria Fabrizio was also well positioned for pastoral agriculture. Located between the marine terrace plateau and the Venella valley, the site had ready access to the well-watered pastures of the valley floor. ${ }^{13}$ Pastoral agriculture in the chora included the raising of sheep and goats, cattle, and pigs. ${ }^{14}$

\footnotetext{
8 Prieto and Carter in Survey, 595; for the geologic orientation of the division lines, see Folk in Survey, 17.

${ }^{9}$ Prieto and Carter in Survey, 596; for the geological context of the chora, see Folk in Survey, ch. 1; for building materials used in the wall foundations, see p. 83 in Ch. 4, "Foundations: Construction materials and methods."

${ }^{10}$ Folk in Survey, 23.

${ }^{11}$ For the location and extent of the marine terraces, see Abbott in Survey, 33, fig. 2.2.

12 For outline of the archaeobotanical studies in the chora and the range of crops that could have been grown locally, see Carter in Survey, 563, 624, fig. 16.6 .

${ }^{13}$ For characterization of the farmhouses along the edge of the valley in the Venella area, see Carter in Survey, 655.

${ }^{14}$ Bökönyi and Gál 2010.
} 


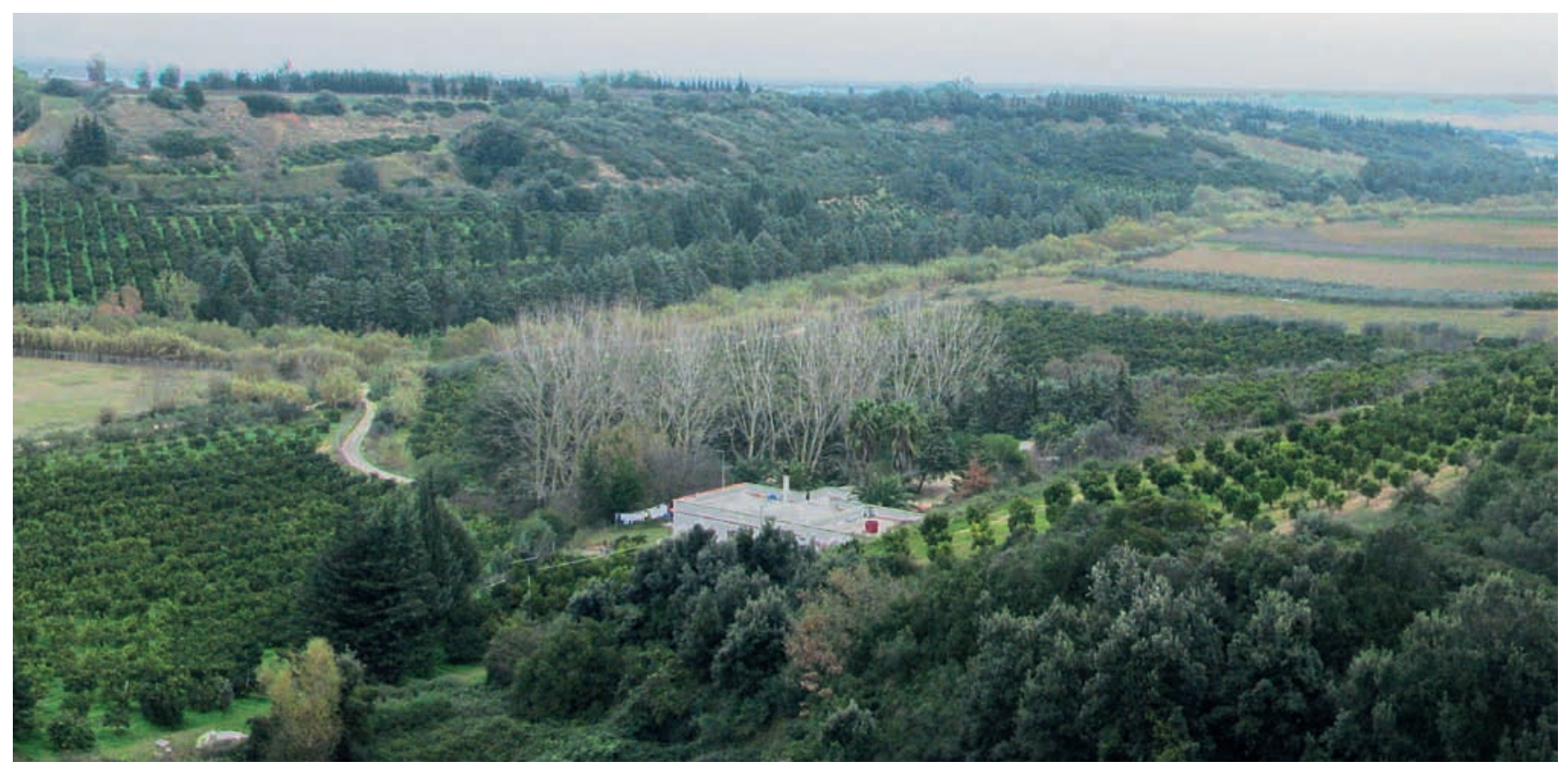

Figure iii General view of the environs of Fattoria Fabrizio from the opposite side of the Venella valley. (ML/ICA)

\section{Environs: The Metaponto Survey}

Fattoria Fabrizio was part of a wider archaeological landscape elucidated by field survey in the chora of Metaponto (see Fig. iv). Initiated a year after the excavations at Fattoria Fabrizio, survey transects between the Bradano and Basento Rivers encompassed Fattoria Fabrizio and its environs, and resulted, ultimately, in the identification of 565 sites dating to the Greek period, including over three hundred sites identified as farmhouses (312). The broad scope of the survey provided a geographical context of long-term change in settlement in the chora. The results of the survey, presented in The Chora of Metaponto 3: Archaeological Field Survey-Bradano to Basento, provide extensive and unparalleled contextualization for the archaeology of Fattoria Fabrizio, one of a half-dozen excavated farmhouses to be presented in the Chora of Metaponto series.

\section{The Metapontine Chora, ca. 375-300 BC}

The site of Fattoria Fabrizio was first occupied in the 6th century BC (see below, p.xxv, "The Archaic Phase"). The main period of the farmhouse at Fattoria Fabrizio, in the 4 th century $\mathrm{BC}$, took place during what has been characterized as a refounding of the polis: a renewal of the urban center, the creation of its theater on the site of the former ekklesiasterion, and of a great stoa in the agora, paralleled by a more productive chora. ${ }^{15}$ The

$\overline{{ }^{15} \text { Carter in Survey, } 809 .}$. quarter-centuries on either side of $350 \mathrm{BC}$ saw a degree of growth that has been described as "exceptional" in comparison to the late 5th and early 4th centuries BC. This growth culminated in the period 325-275 $\mathrm{BC}$, when, after a half-century of relative prosperity in both the chora and the asty, the population of the chora reached its zenith. ${ }^{16}$

The extant farmhouse at Fattoria Fabrizio was established in the late 5 th or early 4 th century BC (for the dating evidence, see Ch. 1), and its occupation extends throughout the 4th century BC. Its abandonment, around or just after ca. $300 \mathrm{BC}$, may have been the result of very local factors, perhaps a landslip. ${ }^{17}$ Fattoria Fabrizio may not be representative of the chora as a whole during the second half of the period 325-275 BC; indeed, other farmhouses were established during the first quarter of the 3rd century BCfor example, the structure above the Pantanello sanctuary. ${ }^{18}$ The site of Fattoria Fabrizio was therefore out of use before the comparative general and widespread decline that characterized the chora from the middle

\footnotetext{
$\overline{16}$ Carter in Survey, 809.

${ }^{17}$ For the archaeological evidence for the nature of the farmhouse's abandonment, see p. 92 in Ch. 4, "Abandonment and Collapse of the Farmhouse."

${ }^{18}$ The sanctuary at Pantanello and its successive phases will be the subject of a future volume in this series. The rural sanctuary was in use until at least ca. $325 \mathrm{BC}$, with a farmhouse established above the Classical-period oikos post- ca. $300 \mathrm{BC}$ and abandoned by or not long after ca. $275 \mathrm{BC}$; cf. Carter in Survey, 880.
} 


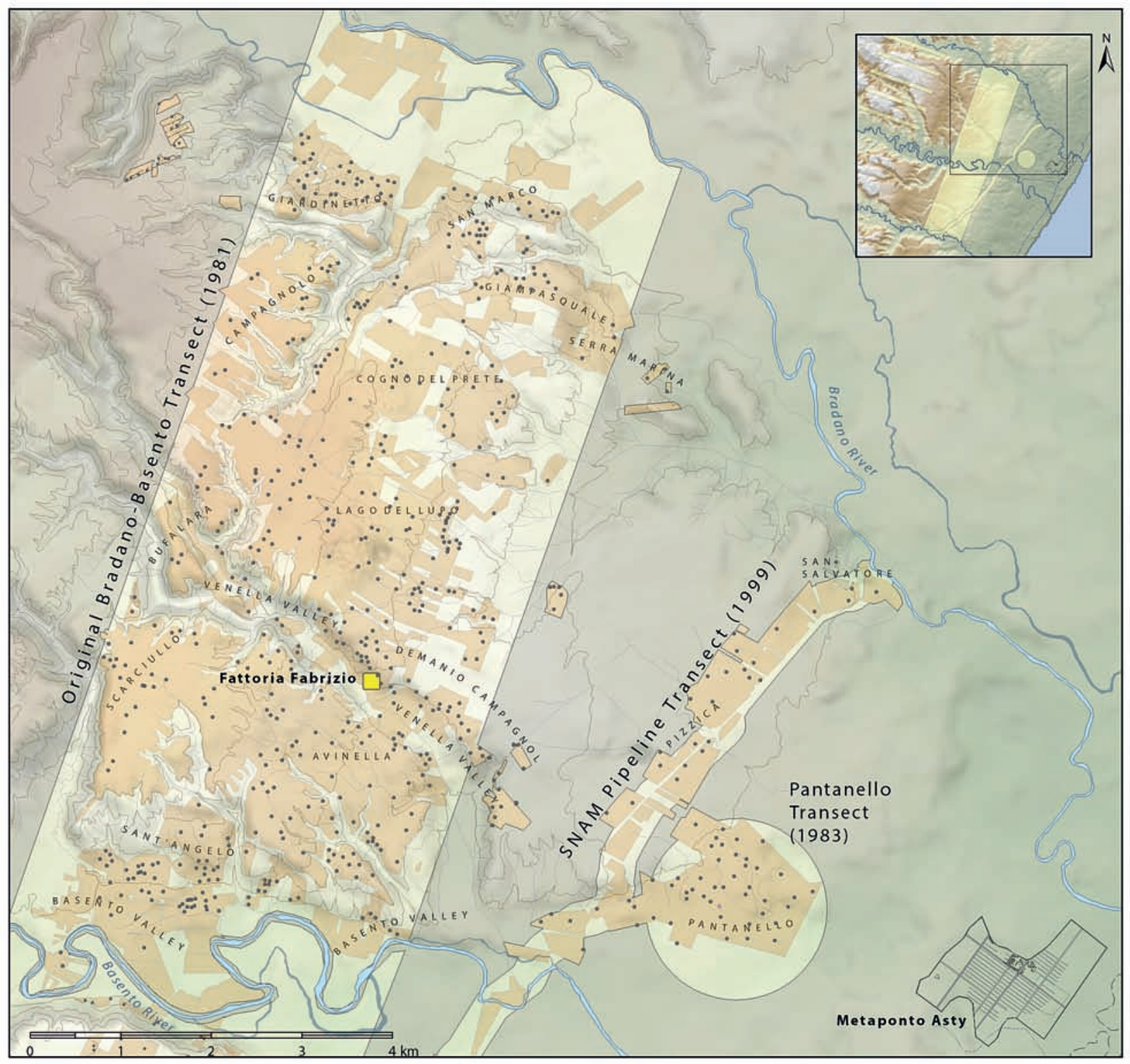

Figure iv Map of the Metapontine chora between the Bradano and Basento Rivers, showing the survey transects, areas, and survey sites. (JT/ICA)

parts of the 3rd century BC. By the middle of the 3rd century BC, only a portion of the farmhouses that had flourished a century earlier were still occupied. ${ }^{19}$

\section{Survey and Sites in the Venella}

The survey evidence shows that the 4th-century BC occupation at Fattoria Fabrizio took place within the context of both very local and region-wide prosperity, reflecting and exceeding that evident from farmhouse sites in the immediate area of Fattoria Fabrizio (Venella), on the marine terraces to the north (Lago

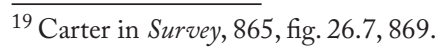

del Lupo) and to the south (Avinella), and throughout the wider Metapontine chora (Fig. v).

The Venella area in the 4th century BC. At least a dozen other farmhouse sites along the middle course of the Venella valley were active in the middle quarters of the 4th century BC. Fattoria Fabrizio, moreover, is situated within an archaeological landscape that consists not only of other farmhouse sites but also of associated necropoleis and two rural sanctuary sites on opposite sides of the floor of the Venella valley. ${ }^{20}$

\footnotetext{
${ }^{20}$ Carter in Survey, 816, fig. 25.8.
} 


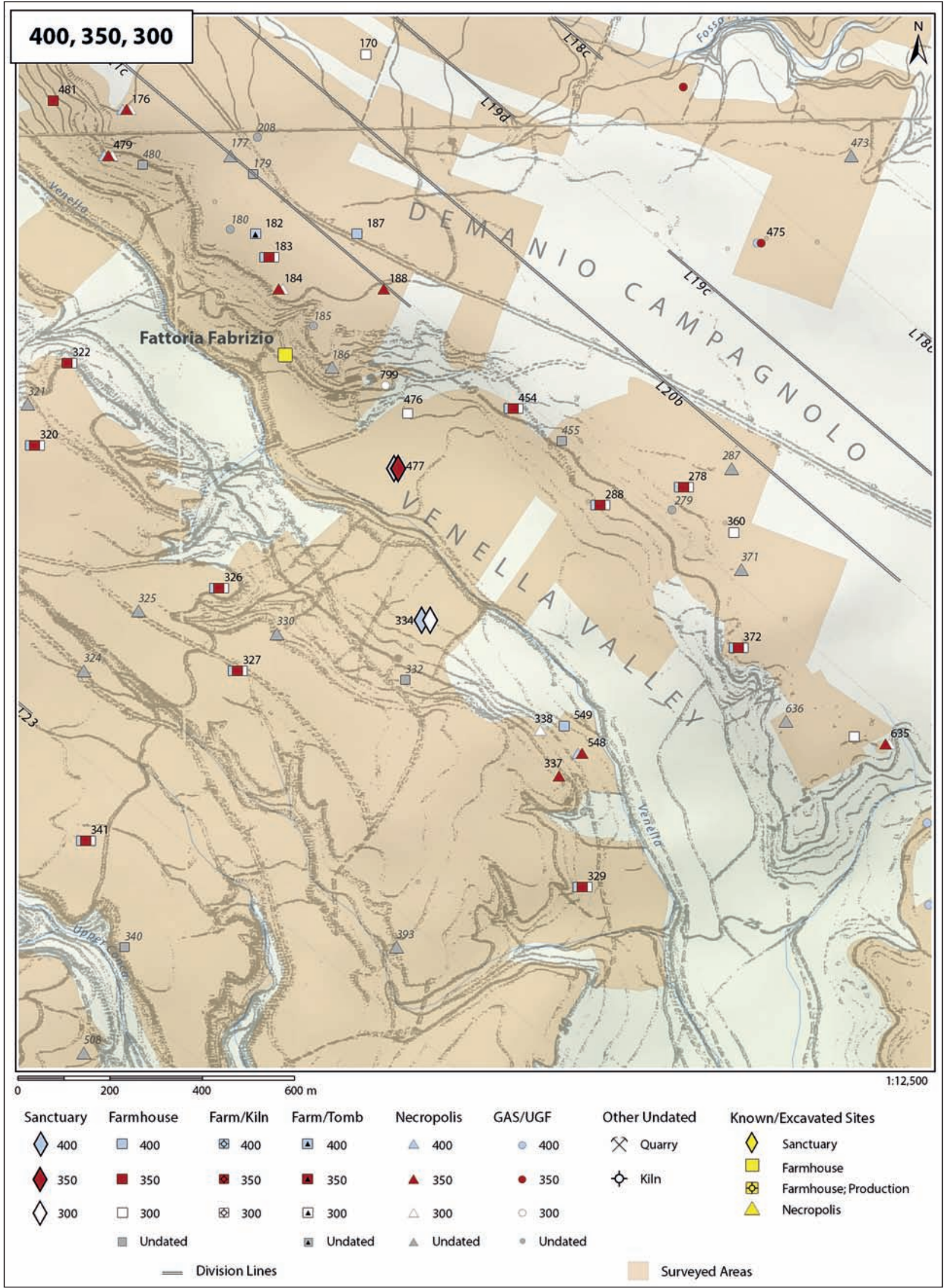

Figure v Map showing the Venella area with sites active between the late 5th and early 3rd C. BC (425-275 BC). (After Survey, fig. 25.8; JT/ICA) 
Fattoria Fabrizio was established during the fiftyyear period 400 (ca. $425-375 \mathrm{BC}$ ). ${ }^{21}$ This was a high point in development of the Venella, with 13 significant farmhouse sites identified in the survey. ${ }^{22}$ When the extant post-Archaic phase of Fattoria Fabrizio was constructed, seven farmhouses appeared ex novo, on sites never before occupied. There was more new building in the Venella in this period than in any other part of the surveyed chora. ${ }^{23}$ Of these, two farmhouse sites in the immediate vicinity of Fattoria Fabrizio, both ca. $300 \mathrm{~m}$ distant and situated on the marine terrace to the north (sites 187 and 182), were active during the period 400 . These ceased to be inhabited by the middle quarters of the 4th century BC. Slightly closer to Fattoria Fabrizio, a third farmhouse (site 183) was active in the late 5 th or 4 th century BC through to the late 4 th or early 3 rd century BC (active in the periods 400,350 , 300; Fig. iv).

Further down the Venella valley, site 454 was an ex-novo site in 400, and ca. $300 \mathrm{~m}$ further on, site 288 had been established in 450 . Both farmhouse sites occupy positions at the crest of the marine terrace plateau, the latter on a projecting spur. ${ }^{24}$

The proliferation of farmhouse sites, including Fattoria Fabrizio, in the area slowed in the late 5 th and early 4th century BC (400). By the middle of the 4th century $\mathrm{BC}$ the farmhouses along the eastern flank of the Venella valley represented a "mature residential community." ${ }^{25}$ During most of the 4th and the early 3rd century $\mathrm{BC}$, the Venella area has been characterized as relatively static . . . it did not decline much in 350 ; it simply did not participate in the growth that is evident elsewhere. The great population boom in the chora in $\mathbf{3 0 0}$ seems to have passed the Venella by. ${ }^{26}$

Indeed, it was in the middle of the latter period (ca. 300 $\mathrm{BC}$ or just after) that Fattoria Fabrizio was abandoned.

The Avinella and Lago del Lupo areas in the 4th century BC. The Venella locale was situated between two areas that saw marked growth and prosperity during

\footnotetext{
${ }^{21}$ The 50-year "date bins" established in Survey are utilized also in this publication; see Carter in Survey, 631. The year $\mathbf{4 0 0}$ in bold font refers to the period $425-375 \mathrm{BC}, 350$ refers to $375-325 \mathrm{BC}$, and so on.

${ }^{22}$ For discussion of the survey evidence for the Venella area in the 4th $\mathrm{c}$. BC, see Carter in Survey, 816, fig. 25.8; see also Figure v, this volume.

${ }^{23}$ Carter in Survey, 818, and n. 13.

${ }^{24}$ Carter in Survey, 818.

${ }^{25}$ Carter in Survey, 818.

${ }^{26}$ Carter in Survey, 816.
}

the course of the 4th century BC. On the marine terraces on either side of the Venella valley, to the north and south of Fattoria Fabrizio, the regions of Avinella and Lago del Lupo witnessed a greater percentage increase in rural population in the period $375-325 \mathrm{BC}$ than did any other part of the chora. ${ }^{27}$

Lago del Lupo, the marine terrace above and behind Fattoria Fabrizio, was a "prime cereal producing area" in which the division lines and many farmhouses were established in the 5 th or early 4th century BC (450 or 400). ${ }^{28}$ The area of Lago del Lupo "experienced sudden expansion in $350 \ldots$.. 29 This area formed the southwestern margin of the extensive Central Plateau which was extremely amenable to arable agriculture. ${ }^{30}$

The farmhouses at the margins of the Venella valley, on the marine terrace opposite Fattoria Fabrizio, continued in use during the entire period that Fattoria Fabrizio was occupied. ${ }^{31}$ In contrast to the eastern edge of the Venella valley, the western margin remained almost unchanged during much of the 4th century BC (350 and 300, ca. 375-275 BC). ${ }^{32}$

The plateau of Avinella on the south side of the Venella valley, opposite Fattoria Fabrizio, saw expansion in 350-a "greater percentage increase in population" than that of Lago del Lupo. ${ }^{33}$ Half of the dozen farmhouses active in the period 350 were already established ex novo in $\mathbf{4 5 0}$ or $\mathbf{4 0 0}$. The new farmhouses were not in immediate proximity to Fattoria Fabrizio, but over $1 \mathrm{~km}$ away in the upper reaches of the Conca valley. ${ }^{34}$ The major changes in the area to the south of Fattoria Fabrizio seem to have taken place further afield. The overall impression is that Avinella, like Lago del Lupo, was "relatively prosperous" in 300 , around the time that Fattoria Fabrizio was abandoned. ${ }^{35}$

Fattoria Fabrizio participated in an expansion where maximum use was made of the land in the area. The survey of the chora suggests that the middle part of the 4th century BC involved a fairly uniform distribution of the farmhouses in Avinella, following a

\footnotetext{
27 "In no part of the study area, except for Lago del Lupo, did the rural population record a greater percentage increase in 350 than it did in Avinella. Only one farmhouse was abandoned while six were added, of which four were ex novo ..." (Carter in Survey, 814).

${ }^{28}$ Carter in Survey, 814.

${ }^{29}$ Carter in Survey, 814, fig. 25.10.

${ }^{30}$ Carter in Survey, 819.

${ }^{31}$ Carter in Survey, fig. 25.5; sites 320, 322, 326, and 327, all active in the periods 400,350 , and 300 .

${ }^{32}$ Carter in Survey, 818.

${ }^{33}$ Carter in Survey, 814.

${ }^{34}$ Carter in Survey, fig. 25.5; sites 343, 345, 350, and 506.

${ }^{35}$ Carter in Survey, 815.
} 
scheme of division into approximately 10-ha plots, consistent with the idealized size of a plot or kleros. ${ }^{36}$

Necropoleis. The Metaponto survey identified three necropoleis in the immediate environs of Fattoria Fabrizio. Site 184 (active in 350 and 300) and site 188 (active in 350) were approximately 200-300 m distant, on the marine terrace known as Demanio Campagnolo. A closer necropolis, site 186, within $200 \mathrm{~m}$ of Fattoria Fabrizio is dated only very generally to the Greek period.

Three more farmhouses, sites 182,183 , and 187 , are also likely to have been associated with necropoleis. ${ }^{37}$ Necropolis site 189 is only $150 \mathrm{~m}$ away from Fattoria Fabrizio, and though closer still to farmhouse site 183, it may have served as a burial place for the occupants of Fabrizio. ${ }^{38}$ It was not unusual to find such a close juxtaposition of several farmhouses to a single necropolis. There were, after all, twice as many farmhouses (312) as necropoleis (161) in the chora. The sharing of a necropolis could indicate familial relationships. The Venella area saw an increase in necropoleis from three to seven in 350, resulting in a higher ratio of necropoleis to farmhouses than any other locality of the survey area. ${ }^{39}$

Rural sanctuaries in the Venella valley. Two sanctuaries in the Venella valley identified in survey, sites 334 and 477 , were part of the cultural landscape characterized by rural sanctuaries placed at springs. ${ }^{40}$ These two sites close to Fattoria Fabrizio seem to form earlier foci and integral parts of settlement in the Venella, which extended along the margins of the valley and edge of the marine terrace. ${ }^{41}$ Both sanctuary sites, as important places of rural worship, antedate the 4th-century BC phase at Fattoria Fabrizio, but there are signs that they were frequented well beyond their heyday in the 6 th century BC. ${ }^{42}$

\footnotetext{
${ }^{36}$ For discussion and the evidence for the Avinella area, see Carter in Survey, 814 and n. 3 .

${ }^{37}$ Carter in Survey, 816.

${ }^{38}$ Carter in Survey, 818.

${ }^{39}$ Carter in Survey, 816.

${ }^{40}$ Site 477 was ca. $400 \mathrm{~m}$ lower down in the Venella valley, and site 334 was on the opposite side of the Venella valley, ca. $400 \mathrm{~m}$ to the southwest of site 477 (n. 47; see also Carter in Survey, 706-9). Other rural sanctuaries further afield include the Pantanello sanctuary, excavated by ICA; for the archaeology of sanctuary sites within the context of the survey see Prieto and Carter in Survey, 612.

${ }^{41}$ Carter in Survey, 816. For discussion of the development of farmhouses in the Venella valley area relation to the two rural sanctuary sites: "The settlement of Venella extended from an original core formed by two early sanctuaries, sites $334 \mathrm{~S}$ and $477 \mathrm{~S}$, along both sides of the valley..." (Carter in Survey, 687).

${ }^{42}$ Site 477 was active in 400 and 350 , and site 334, 400 and 300 (Carter in
}

The Sanctuary of Artemis, further downstream at the mouth of the Venella valley, about $2 \mathrm{~km}$ from Fattoria Fabrizio, is among the earliest sites in the chora, with architectural terracottas dating to the late 7 th century BC. ${ }^{43}$ The Sanctuary of Artemis and the rural sanctuary site 477 on the floor of the Venella were already in existence by the time the first occupation at the site of Fattoria Fabrizio is evident archaeologically in the mid-to-late 6 th century BC. ${ }^{44}$

\section{The Archaic Phase}

The 6th-century BC phase of the site is attested by pottery and other finds in the site assemblage, and by thin Archaic levels found beneath two of the rooms of the farmhouse and in the areas to either side, along the terrace to the northwest and southeast. ${ }^{45}$ Like its 4 thcentury BC successor, the Archaic farmhouse at Fattoria Fabrizio occupied a landscape replete with farmhouses, necropoleis, and rural sanctuaries (Fig. vi). ${ }^{46}$

In its earliest phase, Fattoria Fabrizio seems to have formed part of a cluster of farmhouses with associated sanctuaries - the aforementioned sites 334 and 477as part of a continuum of sites and settlements following a general pattern, which appears to be repeated along the course of the Venella valley. ${ }^{47}$ Nearby farmhouse sites with 6th-century BC phases are sites 181, 182 , and 183 on the plateau above and to the north, and site $454 \mathrm{ca} .500 \mathrm{~m}$ further down the valley. ${ }^{48} \mathrm{Like}$ Fattoria Fabrizio, three of these nearby farmhouse sites were also active in the 4 th century BC. ${ }^{49}$

Survey, 657 , fig. 20.18 , table 20.5). It is within the wider geographical and cultural context of rural sanctuaries at sacred springs that the evidence for domestic cult at Fattoria Fabrizio should be seen (Ch. 5).

${ }^{43}$ For discussion of the Sanctuary of Artemis at San Biagio, see Carter in Survey, 662; De Siena 2007a, 12. For the dating of the earliest architectural element-the terracotta frieze that depicts a hero-see Mertens-Horn 1992. The earliest finds date to the last quarter of the $7 \mathrm{th}$ c. BC (Adamesteanu 1964; 1973, 54; Adamesteanu and Adornato 2001, 264). For the plan of the sanctuary, see Nava 2000, 690, fig. 5. Adamesteanu's suggestion of a cult of Zeus Aglaios was rejected by Lo Porto $(1988,14)$, who proposed that the cippus mentioning Zeus Aglaios (first half of the 6th c. BC) might have been transferred to San Biagio from the urban area in antiquity, and more recently by Osanna $(1992,80)$. For the later Roman-period farmhouse excavated by ICA in the area of the Sanctuary of Artemis, see San Biagio.

${ }^{44}$ Carter in Survey, 672, fig. 20.26

${ }^{45}$ For the nature of the Archaic-period evidence, see p. 7 in Ch. 1, "Chronology and Site Phasing."

${ }^{46}$ For developments in the chora during this period and comprehensive discussion of the Venella area, see Carter in Survey, 677-726, and esp. 685-87 for the Venella.

${ }^{47}$ Carter in Survey, 685-87.

${ }^{48}$ Carter in Survey, fig. 21.7.

${ }^{49}$ Sites $182(400), 183(400,350,300)$, and $454(400,350,300)$. Other excavated examples of 4th-c. BC farmhouses with Archaic phases are known 


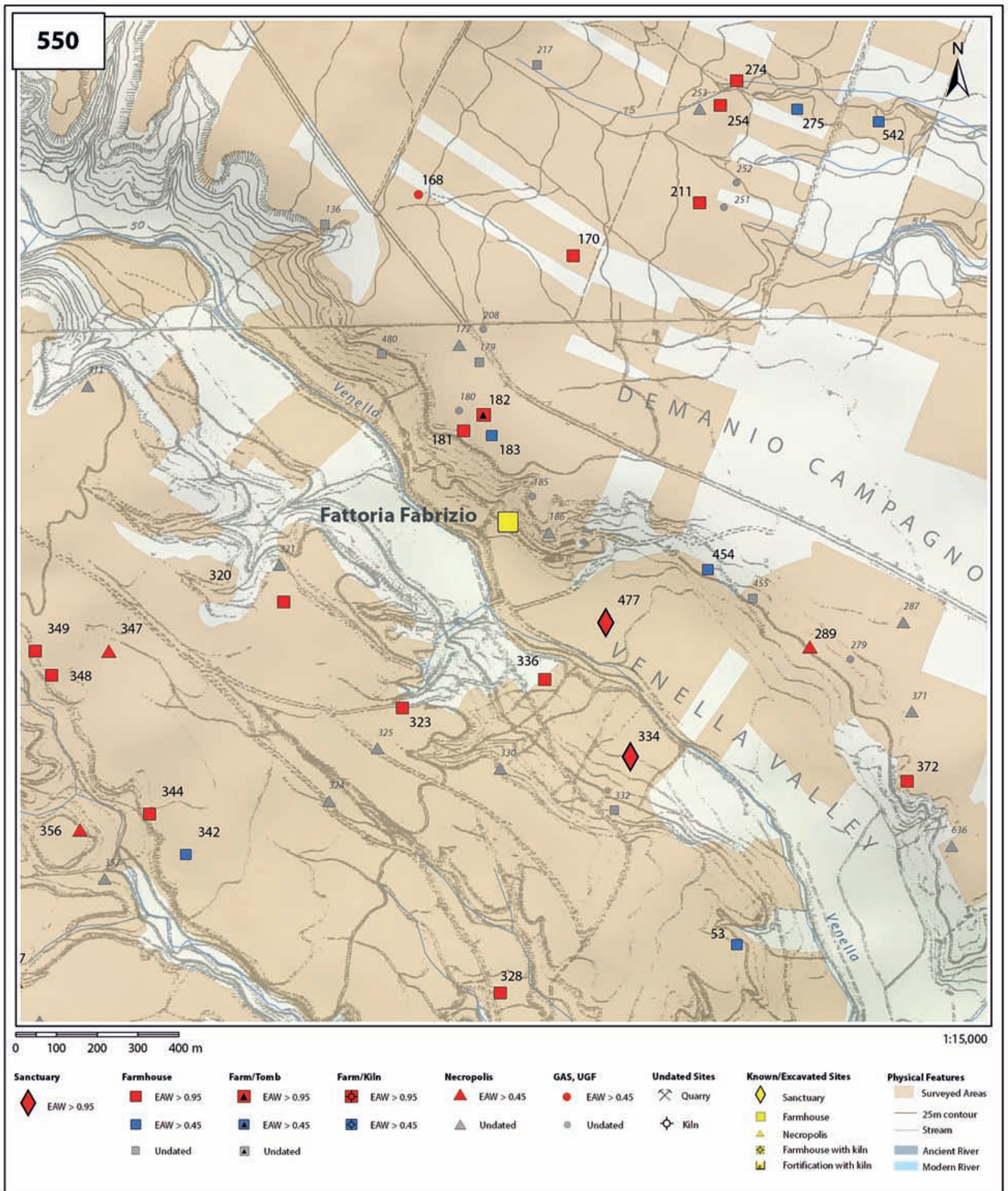

Figure vi Map showing the Venella area, sites active ca. 575-525 BC. (After Survey, fig. 21.7; JT/ICA) 
Necropoleis with an Archaic component are not represented in the immediate vicinity of Fattoria $\mathrm{Fa}-$ brizio. An Archaic necropolis, site 289, was identified on the lip of the marine terrace about $1 \mathrm{~km}$ further down the valley, separated from the Archaic farmhouse site 454 by ca. $400 \mathrm{~m}$. A second, site 635, was likewise ca. $400 \mathrm{~m}$ to the south of the 6th-century BC farmhouse site 372 , in an apparently repeating pattern of site distribution..$^{50}$

On the plateau further from the Venella valley, new settlement in Lago del Lupo formed part of the "momentous advance in the settlement of the chora in the second and third quarters of the 6th century BC..." 51 Established to exploit the Central Plateau for arable

in the chora: see p. 100 in Ch. 4, "Comparable Farmhouse Plans."

50 For discussion of necropoleis in the Venella, see Carter in Survey, 687, fig. 21.7.

${ }^{51}$ Carter in Survey, 688. agriculture, the new farmhouses of the mid-6th century $\mathrm{BC}$ were concentrated in a series of three clusters extending northward across the Central Plateau from Fattoria Fabrizio and the cluster of farmhouse sites 181-183. ${ }^{52}$ On the terrace, the nearest farmhouses (sites 170 and 211) are more than $800 \mathrm{~m}$ from Fattoria Fabrizio and belong to a cluster centered about $1.5 \mathrm{~km}$ distant.

Other farmhouses of the early period are evident opposite Fattoria Fabrizio on the right bank of the Venella: site 323 on the western margin of the Venella, site 336 on the floor of the Venella valley, and site 348 further afield in the Avinella area proper. ${ }^{53}$

\footnotetext{
${ }^{52}$ For discussion of the clusters and distribution of the sites, see Carter in Survey, 689, fig. 21.9. Survey, fig. 21.12 shows a reconstruction of their alignment across the Central Plateau, terminating in the south with the Venella cluster of which Fattoria Fabrizio was a part.

${ }^{53}$ Carter in Survey, 814, fig. 21.7.
} 
